\title{
Verapamil induced premature ventricular beats before reversion of supraventricular tachycardia
}

\author{
Jitu Vohra, Thomas Peter, David Hunt, and Graeme Sloman \\ From the Cardiac Laboratory, The Royal Melbourne Hospital, Victoria, Australia
}

The occurrence in 6 patients of premature ventricular beats before reversion to sinus rhythm, after the intravenous administration of verapamil-for the treatment of supraventricular tachycardia, is reported.

Four patients had pre-excitation syndromes (Wolff-Parkinson-White in I and Lown-Ganong-Levine in 3) and one patient had bradycardia-tachycardia syndrome. In the remaining patient, at previous studies, reciprocating tachycardia had been documented as the mechanism for recurrent supraventricular tachycardia. It is suggested that the supraventricular tachycardia in these 6 patients was probably caused by a reciprocating mechanism.

The patient with bradycardia-tachycardia syndrome developed ventricular tachycardia ("torsades de pointes'). In this and one other patient, the ventricular ectopics were probably responsible for termination of supraventricular tachycardia. The possible mechanisms for the occurrence of premature ventricular beats after verapamil in these patients are discussed.

Verapamil given by intravenous route has been reported to be effective in the treatment of supraventricular tachycardia. Though the exact mechanism of action is uncertain, prolongation of the atrioventricular nodal conduction appears to play an important role (Husaini et al., 1973; Schamroth, Krikler, and Garrett, 1972). Singh and Vaughan Williams (1972) suggest that the antiarrhythmic effect of verapamil may be related to its action in blocking the movement of ionized calcium across the myocardial cell membrane and this property may constitute a new, fourth class antiarrhythmic action.

This paper describes the occurrence of premature ventricular beats associated with verapamil induced reversion to sinus rhythm in 7 episodes of supraventricular tachycardia in 6 patients. In $I$ of these 6 patients short runs of ventricular tachycardia occurred after drug administration. It is suggested that the mechanism of supraventricular tachycardia in these patients was a reciprocating tachycardia and the drug-induced premature ventricular beats were probably responsible for the termination of arrhythmias in at least two instances. The possible mechanism of ventricular ectopics after verapamil, a phenomenon peculiar to reciprocating tachycardia, is discussed.

Received 22 April r974.
Subjects, methods, and results

The 6 patients all had long histories of recurrent supraventricular tachycardia. The clinical details are summarized in the Table.

Of the 6 patients, 4 had pre-excitation syndromes. Case I had Wolff-Parkinson-White syndrome (WPW) type B, and 3 patients (Cases 2, 5, and 6) had Lown-Ganong-Levine (LGL) syndrome (Lown, Ganong, and Levine, 1952). Two patients (Cases 2 and 6) with LGL had previously been admitted with atrial flutter with $I: I$ conduction and ventricular rates of 300 a minute. Intracardiac conduction studies carried out in these 2 patients, while in sinus rhythm, had shown an attentuated AH response to increasing atrial pacing rates, suggesting accelerated atrioventricular conduction (Mandel, Danzig, and Hayakawa, 1971). The technique and normal range for the various components of the intracardiac conduction have been reported previously (Hunt and Vohra, 1973; Hecht et al., 1973). One patient (Case 2) was treated with verapamil on two separate occasions. Case 3 had a bradycardia-tachycardia syndrome (Short, 1954). This patient had normal atrioventricular conduction while in sinus rhythm, but the corrected sinus node recovery time $(850 \mathrm{msec})$ was slightly prolonged (Narula, Samet, and Javier, 1972). A temporary pacemaker electrode had been placed in the right 
TABLE Clinical details

\begin{tabular}{|c|c|c|c|c|c|c|}
\hline $\begin{array}{l}\text { Case } \\
\text { No. }\end{array}$ & $\begin{array}{l}\text { Age } \\
(y r)\end{array}$ & Sex & History & $\begin{array}{l}\text { Electrocardiogram } \\
\text { during sinus rhythm }\end{array}$ & $\begin{array}{l}\text { Other drug therapy } \\
\text { at time of } \\
\text { admission }\end{array}$ & $\begin{array}{l}\text { Previous electro- } \\
\text { physiological studies } \\
\text { while in sinus rhythm }\end{array}$ \\
\hline $\mathbf{I}$ & 43 & $\mathbf{M}$ & $\begin{array}{l}\text { Paroxysmal supra- } \\
\text { ventricular tachy- } \\
\text { cardia for Io yr }\end{array}$ & WPW type B & $\begin{array}{l}\text { Methyldopa } 750 \\
\text { mg/dy; one dose } \\
\text { practolol } 200 \mathrm{mg} \\
\text { orally (before } \\
\text { admission) }\end{array}$ & - \\
\hline 2 & 18 & $\mathbf{M}$ & $\begin{array}{l}\text { Paroxysmal supra- } \\
\text { ventricular tachy- } \\
\text { cardia since child- } \\
\text { hood; atrial flutter } \\
\text { with ventricular rate } \\
\text { of } 300 / \text { min once }\end{array}$ & $\begin{array}{l}\text { PR o.1o sec; } \\
\text { normal QRS } \\
\text { configuration }\end{array}$ & $\begin{array}{l}\text { Digoxin } 0.50 \mathrm{mg} \\
\text { and practolol } \\
200 \mathrm{mg} \text { a day }\end{array}$ & $\begin{array}{l}\text { AH interval } 50 \text { msec } \\
\text { at atrial pacing rates } \\
\text { roo to } 120 \text { and } 60 \text { to } \\
65 \mathrm{msec} \text { at } 130 \text { to } 160 / \\
\text { minute; } \mathrm{HV} \text { interval } \\
30 \mathrm{msec}\end{array}$ \\
\hline 3 & 66 & $\mathrm{~F}$ & $\begin{array}{l}\text { Occasional episodes of } \\
\text { supraventricular } \\
\text { tachycardia for } 30 \mathrm{yr} \text {; } \\
\text { frequent episodes } \\
\text { and attacks of } \\
\text { dizziness for } 3 \mathrm{mth} \text {; } \\
\text { persistent sinus } \\
\text { bradycardia } 40 \text { to } \\
50 / \text { min for many } \\
\text { years }\end{array}$ & $\begin{array}{l}\text { PR o.I6 sec; } \\
\text { sinus brady- } \\
\text { cardia } 40 \text { to } \\
50 / \text { min with } \\
\text { frequent supra- } \\
\text { ventricular } \\
\text { ectopics }\end{array}$ & None for one week & $\begin{array}{l}\text { Corrected sinus node } \\
\text { recovery time } 850 \\
\text { msec; retrograde } \\
\text { P waves following } \\
\text { paced ventricular } \\
\text { beats }\end{array}$ \\
\hline 4 & 47 & F & $\begin{array}{l}\text { Recurrent palpita- } \\
\text { tions for } 12 \mathrm{yr} \text {; } \\
\text { frequent episodes of } \\
\text { supraventricular } \\
\text { tachycardia lasting } \\
\text { for up to } 48 \mathrm{hr} \\
\text { during the last } 4 \mathrm{mth}\end{array}$ & $\begin{array}{l}\text { PR } 0.16 \mathrm{sec} ; \\
\text { digitalis effect }\end{array}$ & $\begin{array}{l}\text { Digoxin } 0.50 \mathrm{mg} \\
\text { and practolol } \\
200 \mathrm{mg} / \text { day }\end{array}$ & $\begin{array}{l}\text { Episodes of supraven- } \\
\text { tricular tachycardia } \\
\text { frequently precipitated } \\
\text { and terminated by in- } \\
\text { duced ventricular } \\
\text { ectopic beats; retro- } \\
\text { grade excitation of } \\
\text { atria demonstrated by } \\
\text { simultaneous low and } \\
\text { high right atrial } \\
\text { electrograms during } \\
\text { episodes }\end{array}$ \\
\hline 5 & 44 & $\mathrm{~F}$ & $\begin{array}{l}\text { History of palpita- } \\
\text { tions for } 30 \mathrm{hr} \text {; } \\
\text { last attack } 12 \mathrm{mth} \\
\text { ago }\end{array}$ & $\begin{array}{l}\text { PR } 0.10 \text { sec; } \\
\text { normal width } \\
\text { QRS }\end{array}$ & Nil & - \\
\hline 6 & I6 & $\mathrm{F}$ & $\begin{array}{l}\text { History of palpita- } \\
\text { tions since childhood; } \\
3 \text { hospital admis- } \\
\text { sions for supra- } \\
\text { ventricular tachy- } \\
\text { cardia; atrial flutter } \\
\text { with I : I conduction } \\
\text { once }\end{array}$ & $\begin{array}{l}\text { PR } 0.10 \mathrm{sec} ; \\
\text { normal width } \\
\text { QRS }\end{array}$ & $\begin{array}{l}\text { Digoxin } 0.5 \mathrm{mg} \text { and } \\
\text { propranolol } \\
120 \mathrm{mg} / \text { day }\end{array}$ & $\begin{array}{l}\text { No increase in AH } \\
\text { (50 msec) interval } \\
\text { on atrial pacing from } \\
74 \text { to } 126 / \mathrm{min} ; \mathrm{HV} \\
\text { interval } 38 \mathrm{msec}\end{array}$ \\
\hline
\end{tabular}

ventricle, but she was not being paced when she developed supraventricular tachycardia. In Case 4, the mechanism of supraventricular tachycardia was diagnosed as a reciprocating tachycardia within the atrioventricular node on the basis of previous electrophysiological studies, during which supraventricular tachycardia was precipitated and terminated by induced premature ventricular beats (Durrer et al., I967).

Verapamil was administered by intravenous injection in increments of $\mathrm{I}$ mg per minute. The electrocardiogram was recorded continuously and the blood pressure was measured every 30 seconds during the injection. The mean dose of verapamil required for reversion was $6.4 \mathrm{mg}$ (range 2 to $10 \mathrm{mg}$ ). None of the patients was in cardiac failure and there were no adverse haemodynamic effects associated with verapamil administration.

\section{Case I: Fig. I}

The electrocardiogram before verapamil shows supraventricular tachycardia at a rate of $185 /$ minute (strip I). Immediately before reversion two premature ventricular beats are recorded (strip 2). The interval between the 


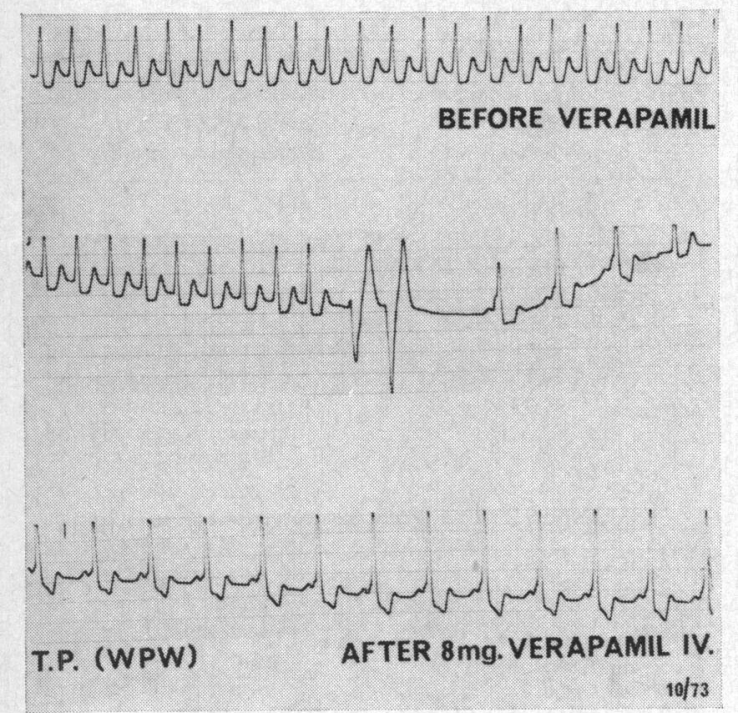

FIG. I Case I: Supraventricular tachycardia in a patient with WPW lead II before and after verapamil. See text for discussion.

last QRS of the supraventricular tachycardia and the first premature ventricular beat is $0.40 \mathrm{sec}$ as compared to $0.32 \mathrm{sec}$ between the QRS complexes during the tachycardia. Sinus rhythm is restored after a pause of I sec and the sinus beats show a typical WPW configuration.

\section{Case 2: Fig. $2 A$}

Supraventricular tachycardia at a rate of $240 / \mathrm{min}$ (strip I) is noted before drug administration. Multiple premature ventricular beats occur before reversion to sinus rhythm and show a slight variation in the QRS configuration. The interval between the last QRS of the supraventricular tachycardia and the first premature ventricular beat is $0.34 \mathrm{sec}$ as compared to $0.30 \mathrm{sec}$ during the tachycardia. A premature ventricular beat is noted in strip 3 after reversion to sinus rhythm.

Fig. $2 \mathrm{~B}$ shows the response to verapamil on a second occasion in the same patient. The 8th complex in strip 2 is, probably, of junctional origin. The 9th and the roth complexes differ from those during supraventricular tachycardia or sinus rhythm in that there is no initial q wave, and suggest that the ventricular activation in the initial part is different, but both middle and terminal vectors are identical to those during supraventricular tachycardia. These beats are, probably, ectopics arising close to the atrioventricular junction, possibly in the anomalous pathway and are followed by a premature ventricular beat. The next two complexes are, probably, fusion beats. A sinus $\mathbf{P}$ wave is noted before the last premature ventricular beat in strip 2. Even after return to sinus rhythm (strip 3), two salvos of premature ventricular beats are noted.

\section{Case 3: Fig. 3}

Strip I shows the electrocardiogram during supraventricular tachycardia. The first complex in strip 2 shows a narrow QRS and is the last complex of the supraventricular tachycardia, this is followed by two early premature ventricular beats and the 4 th complex is again of supraventricular origin, which is followed by a run of ventricular tachycardia. The $Q R S$ complexes during ventricular tachycardia are variable in shape and amplitude and the rate exceeds 200 a minute. After this, the sinus $\mathbf{P}$ wave is seen for the first time before another run of ventricular tachycardia. Strip 3 shows two runs of ventricular tachycardia interspersed with supraventricular tachycardia complexes. The last beat in strip 3
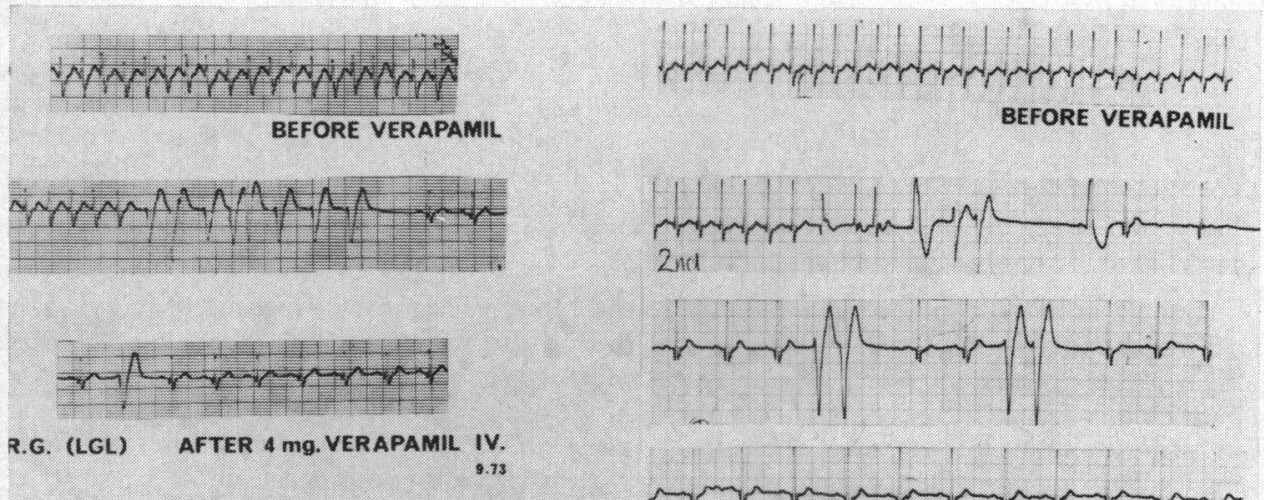

2 nit
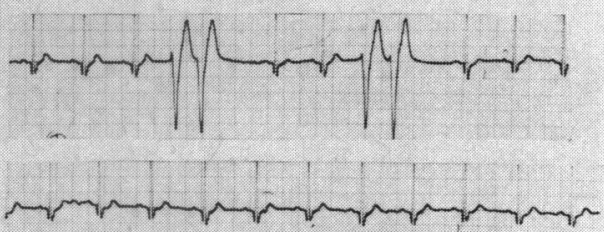

R.G. (LGL) AFTER 2 mg.VERAPAMIL IV.

A

$B$

FIG. 2 Case 2: $A$ and B show leads I and III during two separate episodes of supraventricular tachycardia with ventricular rates of 240 and 215 a minute, respectively. See text for details. 


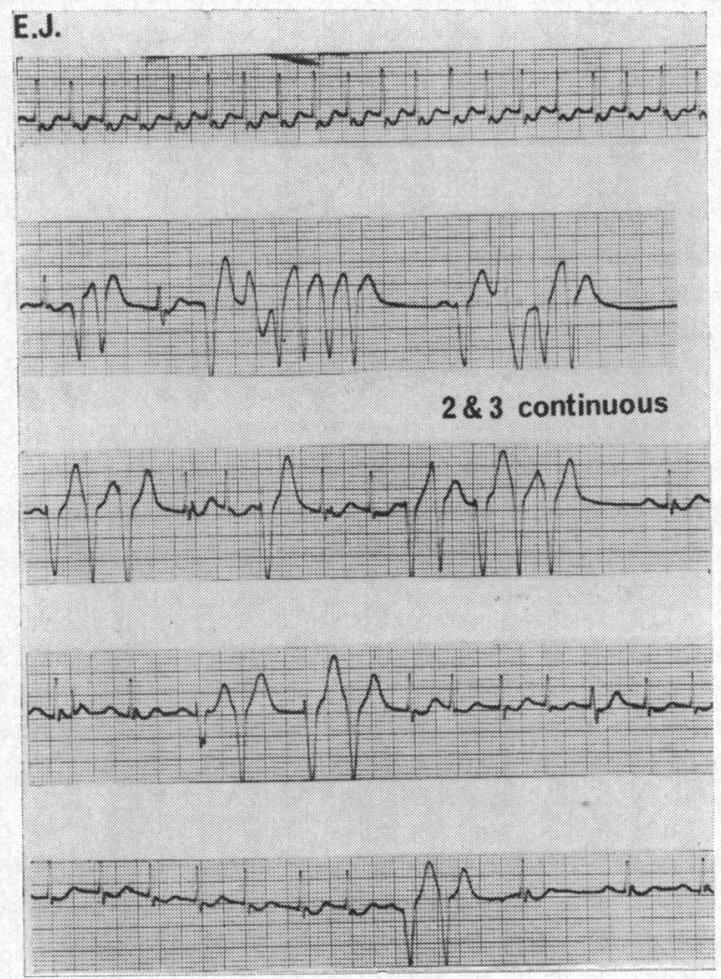

FIG. 3 Case 3: Bradycardia-tachycardia syndrome, supraventricular tachycardia at a rate of 180 a minute before verapamil. Strips 2 to 5 are continuous. The spike after the $Q R S$ of the first complex in strip 4 is an artefact. See text for details.

is of sinus origin, and the first two complexes in strip 4 are of sinus origin (there is a technical artefact after the first QRS of the sinus beat in strip 4). Multiple premature ventricular beats are noted at this stage and the $4^{\text {th }}$ premature ventricular beat restarts the supraventricular tachycardia. Strip 5, again, shows two premature ventricular beats preceding reversion of this episode of supraventricular tachycardia.

\section{Case 4: Fig. 4}

Strip I shows supraventricular tachycardia at a rate of I85 a minute. The 6th complex in strip I is, probably, a fusion beat as the QRS and $T$ axes are different from the preceding complexes. This is followed by two more beats of supraventricular tachycardia. Multiple premature ventricular beats occur next. The interval between the last QRS of the supraventricular tachycardia and the first premature ventricular beat is $0.48 \mathrm{sec}$ as compared to $0.40 \mathrm{sec}$ between the QRS complexes during tachycardia. The last three premature ventricular beats show a different morphology and the 4 th and 5th premature beats are, probably, escape beats. The 3 rd complex in strip 3 is a fusion beat.

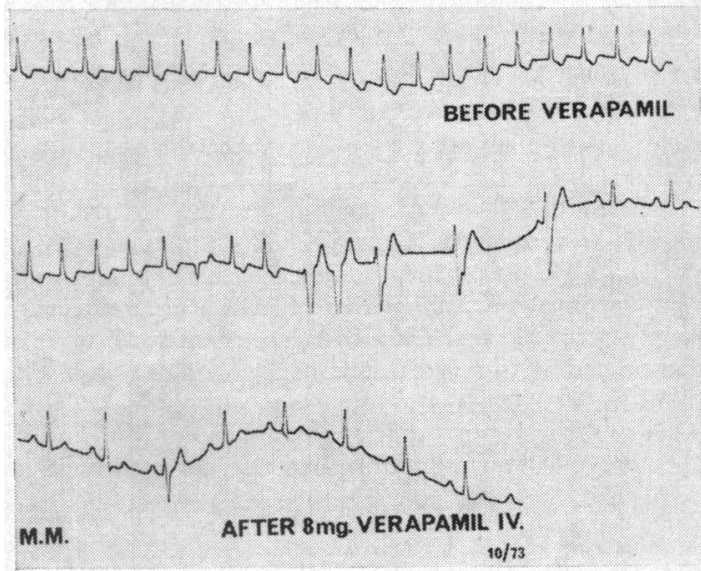

FIG. 4 Case 4: Supraventricular tachycardia at a rate of 150 a minute. See text for discussion.

\section{Case 5: Fig. 5}

Strip I shows supraventricular tachycardia at a rate of 170 a minute. The Ioth and the $13^{\text {th }}$ beats in the second strip are smaller and wider than the QRS complexes during supraventricular tachycardia; however, the $T$ wave axis is in the same direction, suggesting fusion beats. The interval between the last QRS of the supraventricular tachycardia and the first fusion beat is the same as the RR interval during the tachycardia. The I2th and the $13^{\text {th }}$ complexes are premature ventricular beats. Restoration to sinus rhythm is noted after a brief pause and sinus beats show a short PR interval. Two multi-

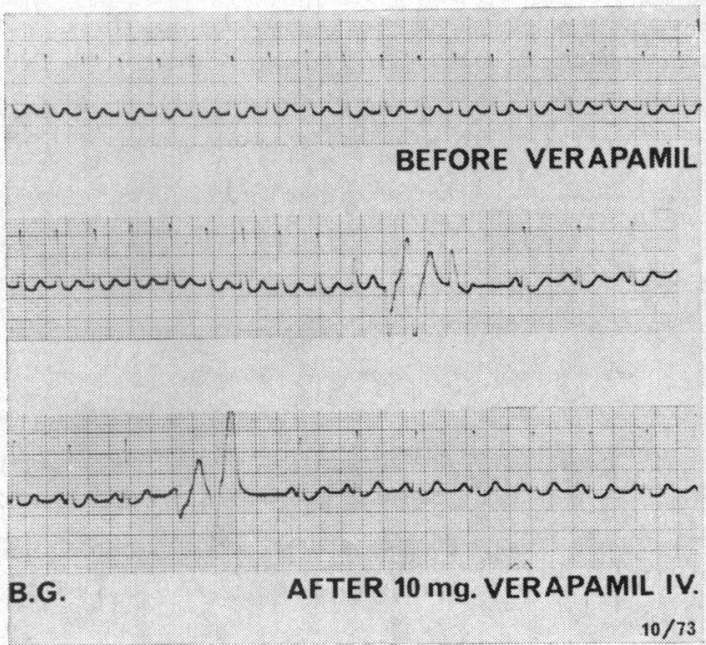

FIG. 5 Case 5: Verapamil for supraventricular tachycardia. Note the short $P R$ interval in sinus beat. see text for the detailed description. 
focal premature ventricular beats are noted in strip 3, even aftet reversion to sinus rhythm.

\section{Case 6: Fig. 6}

Strip I shows supraventricular tachycardia at a rate of I 80 a minute. After $2 \mathrm{mg}$ verapamil, strip 2 shows slight alternation of $R R$ cycle lengths before the occurrence of premature ventricular beats. Three premature ventricular beats are noted and are followed by two supraventricular complexes and a salvo of premature ventricular beats. After this there is a brief pause and a $P$ wave is seen preceding the next premature ventricular beat. The following two beats are sinus beats, though the QRS voltages show some variation. Another run of ventricular tachycardia is noted before the sinus rhythm is estsblished.

\section{Discussion}

Of 6 patients described here, 4 had pre-excitation syndromes. One had WPW, while 3 had LownGanong-Levine syndrome. In the majority of cases with pre-excitation, the mechanism of supraventricular tachycardia is a reciprocating rhythm, utilizing two pathways, one for anterograde and the other for retrograde conduction (Schamroth and Yoshonis, 1969).

One patient had bradycardia-tachycardia syndrome, and reciprocating tachycardias are also frequent in this condition (Easley and Goldstein, 197I). Initiation and termination of the tachycardia by an appropriately timed atrial or ventricular beat is considered to be a strong point in favour of a reciprocating mechanism (Barold et al., 1969; Durrer et al., 1967). In our patient with bradycardiatachycardia syndrome, supraventricular tachycardia was initiated and terminated by premature ventricular beats.

In Case 4, the initiation and termination of tachycardia by induced premature ventricular beats had been demonstrated previously. If, as seems likely, these 6 patients all had reciprocating tachycardia, then termination of the arrhythmia by verapamil induced premature ventricular beats might be easily explained on the basis of interruption of the junctional reciprocating pathway by retrograde penetration of the premature ventricular beat, thus breaking the re-entry cycle (Durrer et al., 1967).

Certainly, in Cases 3 and 5, the premature ventricular beats occur before or at the time of expected arrival of the next supraventricular tachycardia complex and the interruption of the re-entry cycle seems very probable.

Case 3 shows short runs of a ventricular tachycardia which resembles that described as 'torsades de pointes' (Slama et al., 1973). This type of ventricular tachycardia, which borders on ventricular fibrillation, is characterized by irregularity of rate and QRS amplitude, the rate often exceeding 200 a minute. Paroxysms commonly last for 5 to $30 \mathrm{sec}-$ onds and resolve spontaneously. This arrhythmia may occur in the setting of chronic bradycardia and potassium depletion or may occur in response to quinidine or procainamide. Bens et al. (1973) report 2 cases of 'torsades de pointes' and attribute it to prolongation of QT interval caused by prenylamine ('quinidine-like effect'). It is of interest to note that prenylamine has a similar calcium antagonistic effect (Lindner, I97I) to verapamil.

In Cases $1,2,4$, and 6, the interval between the

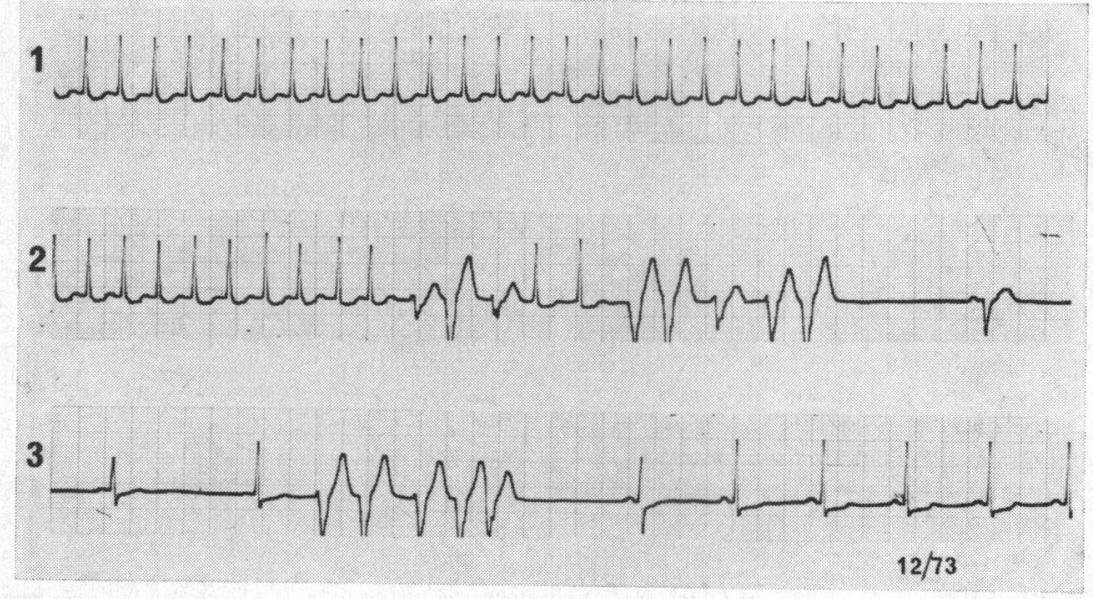

FIG. 6 Case 6: Strips $I$ to 3 are continuous. Slight alternation of $R R$ intervals is noted just before ventricular ectopics preceding reversion to sinus rhythm following $2 \mathrm{mg}$ verapamil. 
last complex of the arrhythmia and the first premature ventricular beat is longer than the interval between the QRS complexes during the arrhythmia. The reversion of supraventricular tachycardia in these 4 patients cannot be attributed to the verapamil induced ventricular ectopics. It is, however, possible that the arrhythmia was terminated by concealed ventricular ectopics. The junction between ventricular muscle and Purkinje fibres is reported to be particularly prone to unidirectional block caused by many conditions (low sodium, high potassium, quinidine, and hypoxia), and usually the block affects anterograde conduction, sparing, or minimally affecting, the retrograde conduction (Bigger, 1973). In the presence of orthograde block, the retrograde conduction has to proceed only up to atrioventricular node ( $\mathrm{NH}$ region) to interrupt the reciprocating pathway and terminate the arrhythmia (Fig. 7). That such selective orthograde block can occur is supported by a report from Samet, Castillo, and Bernstein (1967), who demonstrated retrograde conduction to the atria by rapid ventricular pacing in patients with orthograde block.

Another possibility that deserves consideration is that concealed His bundle ectopics (Rosen, Rahimtoola, and Gunnar, 1970) were responsible for the termination of the arrhythmia in these patients. This suggestion is supported to some extent by the multifocal origin of the premature ventricular beats and the atrioventricular nodal ectopics in one patient. If the arrhythmia were terminated by concealed ventricular or His bundle ectopics, the first apparent premature ventricular beats, seen in the electrocardiograms here, were in fact, the second ectopic beats.

In Case 6 (Fig. 6) the ventricular ectopics are preceded by alternation of RR cycle lengths. The

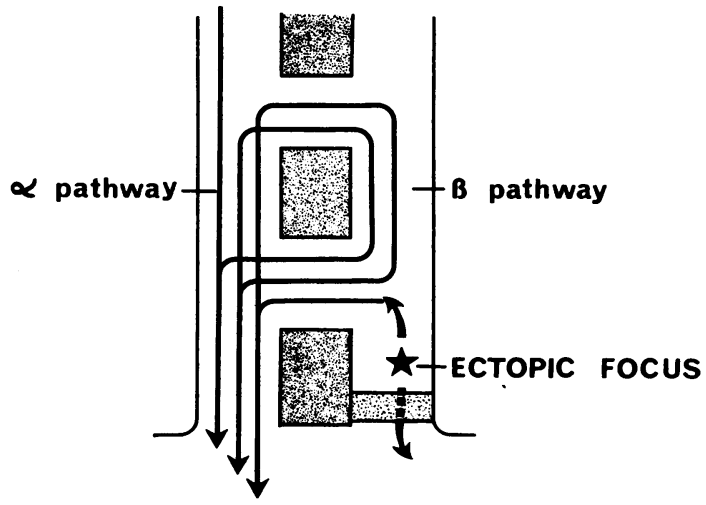

FIG. 7 Interruption of the reciprocal pathway by a premature ventricular beat in the presence of orthograde block. subject of alternation of $R R$ cycle lengths has been discussed in detail in previous publications (Spurrell, Krikler, and Sowton, 1973; Vohra et al., 1974). Such alternation in reciprocating tachycardia has been attributed to the unmasking of an additional pathway for anterograde conduction due to a $2: 1$ block in the original anterograde pathway or a $3: 2$ Wenckebach block in the final pathway. It is thus possible that reversion to sinus rhythm was caused by the drug induced block in the additional anterograde pathway. However, in none of the 4 cases of alteration of cycle length following verapamil reported by us, did ventricular ectopics precede reversion to sinus rhythm.

The possibility that these premature ventricular beats were caused by an escape ventricular rhythm occurring after the termination of supraventricular tachycardia was also considered. However, such a rhythm is usually regular, of unifocal origin, and even with an accelerated idioventricular rhythm, the rate does not normally exceed roo a minute (Rothfeld et al., 1968). In our patients, salvos of premature ventricular beats had rates of between 150 and 200 a minute.

It is apparent that the premature ventricular beats are not supraventricular ectopics with aberrant conduction, as they are not consistently preceded by longer RR cycles (Moe and Mendez, I97I). Fusion beats are frequently noted and some premature ventricular beats show atrioventricular dissociation.

It is noteworthy that in Case 2, an identical response was noted on two different occasions. It is, therefore, suggested that the emergence of a ventricular extrasystolic pacemaker was related to the administration of verapamil. One possible explanation for these drug induced premature ventricular beats in these patients may be that the arrival of the supraventricular impulse at the semi-protected cell enhances the ectopic charge by 'electrotonic influence'. This enables the ectopic charge to reduce threshold quickly, and the action potential is, thereby, prematurely precipitated (Schamroth, 1966). The electrotonic influence is the property which is likely to have been accentuated by the drug. The mechanism of facilitation, itself, may be a Wedensky phenomenon (Wedensky, 1903), or it may be a sudden dissipation of a pre-existing exit block around an ectopic pacemaker caused by verapamil.

Alternatively, the drug, because of its effect on the calcium ion transfer across the cell membrane, may have caused an abrupt reduction in the resting potential/threshold potential difference, either by lowering threshold or by reducing the resting potential.

Verapamil does not affect the maximum rate of 
depolarization or the duration of action potential, and the antiarrhythmic property of the drug has been attributed to its action of blocking the movement of ionized calcium across the cell membrane. It is probable that the ventricular ectopics in these patients reflect the transient, abnormal, unstable state of calcium flux produced by verapamil.

The role of calcium in the genesis of cardiac arrhythmia is extremely complex and depends on the dosage and the species studied, administration of other compounds; and electrolyte status, in particular, the potassium concentration. Both hypocalcaemia and hypercalcaemia have been reported to produce ectopic rhythms (Scherf and Schott, 1973). Though an increase in calcium decreases the excitability and vice versa, in the presence of normal $\mathrm{K}^{+}$and $\mathrm{Mg}^{++}$large changes in calcium concentration can occur before affecting the action potential of the Purkinje fibres. The effects of high $\mathrm{Ca}^{++}$ counteracts the effects of high $\mathrm{K}^{+}$and the reverse also applies (Zipes, 1973).

Under experimental conditions, a reduction in extracellular calcium concentration causes delayed repolarization and oscillatory changes in membrane potential (Hoffman and Suckling, 1956). It has been suggested that these changes may initiate ectopic beats (Hoffman and Cranefield, 1964). However, recent experimental studies in the genesis of ventricular fibrillation have shown the importance of 'slow response' or action potential of partially depolarized fibres, which depend on the smaller currents arising from permeation of calcium ions (Cranefield, 1973). Verapamil, by its action in blocking the calcium uptake, acts as a slow channel inhibiting agent (Zipes, Fischer, and Nicoll, 1973; Watanabe and Besch, 1973) and should provide protection against re-entrant ventricular arrhythmias.

Although primarily used for treatment of supraventricular tachycardia, verapamil has been reported to reduce the frequency of premature ventricular beats (Schamroth et al., 1972). Under experimental conditions, verapamil also protects against catecholamine induced ventricular arrhythmias and fibrillation (Melville, Shister, and Huq, 1964; Hanna and Schmid, 1970; Kaumann and Aramendia, 1968). In the light of these reports, the occurrence of premature ventricular beats in the patients described here is a highly unusual response to verapamil.

The appearance of verapamil induced premature ventricular beats before termination of supraventricular beats appears to be peculiar to reciprocating tachycardia. We have noticed it only in the 6 patients reported here out of some 5o patients with supraventricular tachycardia treated with intravenous verapamil. Husaini et al. (1973), who studied the effects of verapamil on intracardiac conduction in patients in sinus rhythm, also made no mention of ectopic activity after the drug administration.

A possible explanation for the occurrence of verapamil induced premature ventricular beats in reciprocating tachycardia may be the proximity of the ectopic pacemaker to the alternate circuit, so that the discharge from this focus can emerge in the relative refractory period of the intraventricular conduction system. Further studies using $\mathrm{His}$ bundle electrograms, either during spontaneous or induced reciprocating tachycardia and its treatment by intravenous verapamil, should throw more light on the exact origin of verapamil induced ectopic activity and its possible role in termination of the arrhythmia.

We have observed four types of response to the administration of verapamil in supraventricular tachycardia before reversion to sinus rhythm.

I. Abrupt termination of arrhythmia as with carotid sinus pressure.

2. Slight reduction in the ventricular rate caused by delayed AV conduction followed by a short pause before reversion to sinus rhythm - a common response to beta-adrenergic receptor blockers.

3. Alternation of RR cycle lengths before reversion to sinus rhythm, which is preceded by a shorter RR cycle length.

4. Occurrence of ventricular ectopics followed by a pause and return to sinus rhythm.

It is felt that the type 4 response is peculiar to reciprocating tachycardia and type 3 is a very strong point in favour of intranodal reciprocation.

\section{References}

Barold, S. S., Linhart, J. W., Samet, P., and Lister, J. W. (1969). Supraventricular tachycardia initiated and terminated by a single electrical stimulus. American fournal of Cardiology, 24, 37.

Bens, J. L., Duboisset, M., Quiret, J. C., Lesbre, J. P., and Bernasconi, P. (1973). Syncopes par torsades de pointes induites ou favorisées par la prénylamine. Archives des Maladies du Coeur et des Vaisseaux, 66, 1427.

Bigger, J. T. (1973). Electrical properties of cardiac muscle and possible causes of cardiac arrhythmias. In Cardiac Arrhythmias, Twenty-fifth Hannemann Symposium, p. 13. Ed. by L. S. Dreifus and W. Likoff. Grune and Stratton, New York.

Cranefield, P. F. (1973). Ventricular fibrillation. New England fournal of Medicine, $289,732$.

Durrer, D., Schoo, L., Schuilenburg, R. M., and Wellens, H. J. J. (1967). Role of premature beats in the initiation and the termination of supraventricular tachycardia in the Wolff-Parkinson-White syndrome. Circulation, 36, 644.

Easley, R. M., and Goldstein, S. (197I). Sino-atrial syncope. American fournal of Medicine, 50, 166. 
Hanna, C., and Schmid, J. R. (1970). Antiarrhythmic action of coronary vasodilator agents papavarine, dioxyline and verapamil. Archives Internationales de Pharmacodynamie et de Thérapie, 185, 228.

Hecht, H. H., Kossmann, C. E., Childers, R. W., Langendorf, R., Lev, M., Rosen, K. M., Pruitt, R. D., Truex, R. C., Uhley, H. N., and Watt, T. B. (I973). Atrioventricular and intraventricular conduction. Revised nomenclature and concepts. American fournal of Cardiology, 31, 232.

Hoffman, B. F., and Cranefield, P. F. (1964). The physiological basis of cardiac arrhythmias. American fournal of Medicine, 37, 670.

Hoffman, B. F., and Suckling, E. E. (1956). Effect of several cations on transmembrane potentials of cardiac muscle. American fournal of Physiology, 186, 317.

Hunt, D., and Vohra, J. (1973). Clinical applications of His bundle electrography. Medical fournal of Australia, I, 373.

Husaini, M. H., Kvasnicka, J., Rydén, L., and Holmberg, S. (1973). Action of verapamil on sinus node, atrioventricular, and intraventricular conduction. British Heart Fournal, 35, 734.

Kaumann, A. J., and Aramendia, P. (1968). Prevention of ventricular fibrillation induced by coronary ligation. Fournal of Pharmacology and Experimental Therapeutics, $164,326$.

Lindner, E. (1971). The pharmacology of prenylamine. Clinical Trials fournal, Vol. 8, Suppl. I, 6.

Lown, B., Ganong, W. F., and Levine, S. A. (1952). The syndrome of short P-R interval, normal $Q R S$ complex and paroxysmal rapid heart action. Circulation, 5, 693.

Mandel, W. J., Danzig, R., and Hayakawa, H. (1971). LownGanong-Levine syndrome: a study using His bundle electrograms. Circulation, 44, 696.

Melville, K. I., Shister, H. E., and Huq, S. (1964). Iproveratril: experimental data on coronary dilatation and antiarrhythmic action. Canadian Medical Association fournal, 90, 76r.

Moe, G. K., and Mendez, C. (1971). Functional block in the intraventricular conduction system. Circulation, 43, 949.

Narula, O. S., Samet, P., and Javier, R. P. (1972). Significance of the sinus-node recovery time. Circulation, 45, 140.

Rosen, K. M., Rahimtoola, S. H., and Gunnar, R. M. (1970). Pseudo A-V block secondary to premature nonpropagated His bundle depolarizations: documentation by His bundle electrocardiography. Circulation, 42, 367.

Rothfeld, E. L., Zucker, I. R., Parsonnet, V., and Alinsonorin, C. A. (1968). Idioventricular rhythm in acute myocardial infarction. Circulation, 37, 203.

Samet, P., Castillo, C., and Bernstein, W. H. (1967). Studies in $\mathrm{P}$ wave synchronization. American fournal of Cardiology, 19, 207.
Schamroth, L. (1966). Genesis and evolution of ectopic ventricular rhythm. British Heart fournal, 28, 244.

Schamroth, L., Krikler, D. M., and Garrett, C. (1972). Immediate effects of intravenous verapamil in cardiac arrhythmias. British Medical fournal, $1,660$.

Schamroth, L., and Yoshonis, K. F. (1969). Mechanisms in reciprocal rhythm. American fournal of Cardiology, 24, 224.

Scherf, D., and Schott, A. (1973). Extrasystoles and Allied Arrhythmias, 2nd ed., p. 784. William Heinemann Medical Books, London.

Short, D. S. (1954). The syndrome of alternating bradycardia and tachycardia. British Heart fournal, 16, 208.

Singh, B. N., and Vaughan Williams, E. M. (1972). A fourth class of antidysrhythmic action? Effect of verapamil on ouabain toxicity, on atrial and ventricular intracellular potentials and on other features of cardiac function. Cardiovascular Research, 6, 109.

Slama, R., Coumel, P., Motte, G., Gourgon, R., Waynberger, M., and Touche, S. (1973). Tachycardies ventriculaires et torsades de pointes. Frontiéres morphologiques entre les dysrhythmies ventriculaires. Archives des Maladies $d u$ Coeur et des Vaisseaux, 66, 1401.

Spurrell, R. A. J., Krikler, D., and Sowton, E. (1973). Two or more intra AV nodal pathways in association with either a James or Kent extranodal bypass in 3 patients with paroxysmal supraventricular tachycardia. British Heart fournal, 35, 113.

Vohra, J., Hunt, D., Stuckey, J., and Sloman, G. (1974). Cycle length alternation in supraventricular tachycardia following administration of verapamil. British Heart fournal, 36, 570 .

Watanabe, A. M., and Besch, H. R. (1973). Effects of inotropic agents on systolic transmembrane calcium flux. Circulation, 47 and 48, Suppl. IV, II.

Wedensky, N. E. (1903). Die Erregung, Hemmung und Narkose. Pflügers Archiv für die gesamte Physiologie, 100, I.

Zipes, D. P. (1973). Electrolyte derangements in genesis of arrhythmias. In Cardiac Arrhythmias, Twenty-fifth Hannemann Symposium, p. 55. Ed. by L. S. Dreifus and W. Likoff. Grune and Stratton, New York.

Zipes, D. P., Fischer, J. C., and Nicoll, A. de B. (1973). Effect of slow channel inhibiting agents on sinus node automaticity and A-V conduction. Circulation, 47 and 48, Suppl. IV, 2 I.

Requests for reprints to Dr. Jitu Vohra, Cardiac Department, Royal Melbourne Hospital, Victoria 3050, Australia. 